\title{
Programmed Cell Death Protein 5
}

National Cancer Institute

\section{Source}

National Cancer Institute. Programmed Cell Death Protein 5. NCI Thesaurus. Code C115261.

Programmed cell death protein 5 (125 aa, $14 \mathrm{kDa})$ is encoded by the human PDCD5 gene. This protein is involved in the promotion of apoptosis. 